\title{
TRACTOR PERFORMANCE IN SOWING WITH FURROWER CONFIGURATIONS IN AREAS WITH CONTROLLED TRAFFIC OF MACHINES
}

\author{
Gilvan M. Bertollo ${ }^{*}$, José F. Schlosser ${ }^{2}$, Rovian Bertinatto ${ }^{2}$, Alfran T. Martini², Iury Y. P. Rüdell ${ }^{2}$ \\ $1^{*}$ Corresponding author. Universidade do Noroeste do Estado do Rio Grande do Sul - UNIJUI/ Ijuí - RS, Brasil. \\ E-mail: gilvanbertollo@yahoo.com.br
}

\author{
KEYWORDS \\ traction force, traffic \\ lanes, engine, \\ furrower.
}

\begin{abstract}
The controlled traffic of machines is a technique that performs the standardization of machine wheel gauges and width of implements, allowing them to move in predetermined places. The objective of this study was to evaluate the performance of an agricultural tractor, pulling seeder with configurations of furrows, in an area with controlled traffic of machines in various intensities. The study was developed in an agricultural area located in the municipality of Carazinho, RS. The experimental design was 3 x 3 randomized blocks, with traffic conditions (tractor traffic, tractor and harvester traffic, other tractor traffic, harvester and sprayer) and three configurations of furrows (double disk, double disk in the rows without traffic and rod in the traffic and double disk in the rows without traffic and without furrower in the lanes of traffic). The variables analyzed were traction force, power in the drawbar, maximum power, speed, skidding, operational capacity and efficiency of the engine. It was concluded that the absence of furrows in controlled traffic lanes provides reduction of traction force. The power demand of the seeder decreases when the rod-type furrow is replaced by double disc and this reduction is even greater when removed from the traffic lanes in situations of higher traffic intensity.
\end{abstract}

\section{INTRODUCTION}

Brazil has become a major producer of the main agricultural crops. The soybean area is expected to increase significantly over the next 10 years. To manage cultures, since implantation, cultural dealings and harvesting, agricultural machines and equipment traffic on the ground to perform their functions. With the modernization of agriculture, the machinery and implements mass, and the intensity of soil use have increased (Streck et al., 2004), and this may cause soil compaction.

The traffic of machines of different masses, together with the intensity of passes, can interfere in the physical attributes of the soil so that they become restrictive for root and plant development (Cortez et al., 2014). The compaction is directly related to soil quality, and occurs due to the pressure applied by the machine wheels or trampling of animals, exceeding the load bearing capacity that the soil offers (Mazurana et al., 2013).

A mechanical alternative for the reduction of problems caused by compaction of areas in no-tillage system is the use or the deepening of the action of the furrow rod for fertilizer deposition at the moment of sowing (Nunes et al., 2015). However, subsoil operation using rods influences the need for increased energy demand and the increase of the tractor's skidding, requiring more tractive force to work at greater depths (Cepik et al., 2010).

The controlled traffic system can reduce traction demand significantly by lower rolling resistance of the tire due to displacement in permanently trafficked areas and less demanding when opening the furrow in areas with lower compaction occupied by areas for cultivation of plants and without machine traffic (Chen \& Yang, 2015). In controlled traffic, occurs the displacement of wheelsets in compacted tracks, increasing the traction of the machines and boosting the field efficiency of the equipment during agricultural operations (Rosset \& Rampim, 2013).

The adoption of controlled traffic of machines allows improvements in the physical structure of the soil and reduction in the fuel consumption, since a larger area of soil will not be compacted and will present less resistance to soil rupture in the passage of implements of mobilization, as well as improvement of the tractor's traction potential (tire-soil relation), which increases the efficiency of the traction, result of the traffic of the machinery on firmer soil (traffic lanes) (Roque et al., 2010)

Therefore, the objective of this study was to evaluate the performance of an agricultural tractor in the sowing operation with types of furrowers in the sowing, in areas with controlled traffic of machines at various intensities.

\footnotetext{
${ }^{2}$ Universidade Federal de Santa Maria - UFSM, Santa Maria, Brasil.

Received in: 4-16-2018

Accepted in: 8-7-2018
} 


\section{MATERIAL AND METHODS}

The research was carried out in the municipality of Carazinho, RS, in a rural property that has used for three years the controlled traffic system of machines. The soil of the site is classified as Red Latosol, of clay texture (55\% of clay) with relatively flat topography. The area had been cultivated for more than a decade, with annual crops such as soybean, wheat and oats, characterizing a consolidated no-tillage system. In the experiment the area presented cultural remains of the soybean crop, whose harvest had been carried out at 20 days and presented 2.297 $\mathrm{Mg} \mathrm{ha}^{-1}$ of dry matter. The soil water content on the day of the study was $22.4 \% ; 20.3 \% ; 21.8 \%$; and $22.8 \%$ at depths of $0-0.05$ $\mathrm{m} ; 0.05-0.1 \mathrm{~m} ; 0.1-0.15 \mathrm{~m}$ and $0.15-0.2 \mathrm{~m}$, respectively.

The rural property has its machines with wheelset gauges adapted for this type of operation, all with horizontal free span of $3 \mathrm{~m}$. The machines feature a satellite navigation system of the Global Navigation Satellite System type (GNSS) -Real-Time Extended (RTX), with centimeter accuracy $(0.04 \mathrm{~m})$ and autopilot, to maintain the direction and accuracy of traffic on the determined lane, concentrating all traffic of the machines in defined places, being possible to maintain the lanes of the machines circulation permanent over the years.

The tractor used for the sowing operation in the controlled traffic was Massey Ferguson, model MF 7415 Dyna6, auxiliary front wheel drive (AFWD), with cabin, manufactured in the year 2014. It is equipped with fourcycle diesel engine with six vertical cylinders, in line, with two valves per cylinder, totaling a cylinder capacity of 7400 $\mathrm{cm}^{3}$. It features turbocharger with intercooler, providing rated power, according to the dynamometric evaluation performed of $145.6 \mathrm{Kw}$ at $1795 \mathrm{rpm}$, and maximum torque of $893 \mathrm{Nm}$ at $1402 \mathrm{rpm}$. In the experiment performing, the tractor had 1200 hours of work.

The tractor was equipped with Goodyear-branded front wheels, specification 18.4-26 R1 and Firestone rear wheels, specification $30.5 \mathrm{~L} 32 \mathrm{R} 1$. The four wheelsets had hydraulic lifting of $75 \%$ of the total volume, besides metal stripping, with 34 metallic blocks in the front support, and four masses of $50 \mathrm{~kg}$ and one of $200 \mathrm{~kg}$ in the rear wheel, adding $400 \mathrm{~kg}$ per rear wheelset rim, totaling a total tractor mass of $11,690 \mathrm{~kg}$ giving a mass/power ratio of $80.29 \mathrm{~kg}$ $\mathrm{kW}^{-1}\left(59.1 \mathrm{~kg} \mathrm{hp}^{-1}\right)$. The tire inflation pressure was adjusted to $144.7 \mathrm{kPa}\left(21 \mathrm{lbf} \mathrm{in}^{-2}\right)$ for the front wheels and $70.3 \mathrm{kPa}$

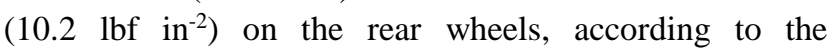
manufacturer's recommendation. The tractor mass distribution was $60.3 \%$ and $39.7 \%$ on the rear and front axles, respectively.

Two seeder-fertilizer drills Semeato, model SSM 27 were used, of tractive drawbar in the form of tandem, configured with 52 sowing rows, spaced at $0.17 \mathrm{~m}$. In order to simulate ideal field conditions, we used seedling ballasting with $2,060 \mathrm{~kg}$ of fertilizer in the reservoirs, characterizing half the maximum storage capacity of seeds and fertilizers. The seeder operated lubricated and with inflation pressure of the four tires of $275.8 \mathrm{kPa}\left(40 \mathrm{lbf} \mathrm{in}{ }^{-2}\right)$.

The research was conducted in randomized blocks, in two-factorial statistical design, with three traffic situations (tractor traffic, tractor and harvester traffic, other tractor traffic, harvester and sprayer) and three configurations of furrower (double disk in all seeding rows, double disk in the rows without traffic and rod in those that receive the traffic, double disk in the rows without contact of tire and absence of double disk furrow type and rod in the traffic lanes). The data collection was performed in $50 \mathrm{~m}$ length in three blocks, totaling 27 experimental units.

The traffic situation factor in the controlled system was composed, initially, by the tractor pass only, characterizing its traffic in area without traffic (WT), which shifted by traction of the seeder outside the demarcated lanes to traffic (Figure 1A). The second level was characterized by the sum of the tractor pass in the sowing operation and the harvester in the soybean harvest, characterizing tractor and harvester $(\mathrm{TH})$ (Figure 1B). The third level was composed of the sum of the traffic of the tractor in the sowing operation, the harvester in the soybean harvest and of the sprayer in the cultural tracts, which totaled seven traffics, characterizing tractor, harvester and sprayer (THS) (Figure 1C).
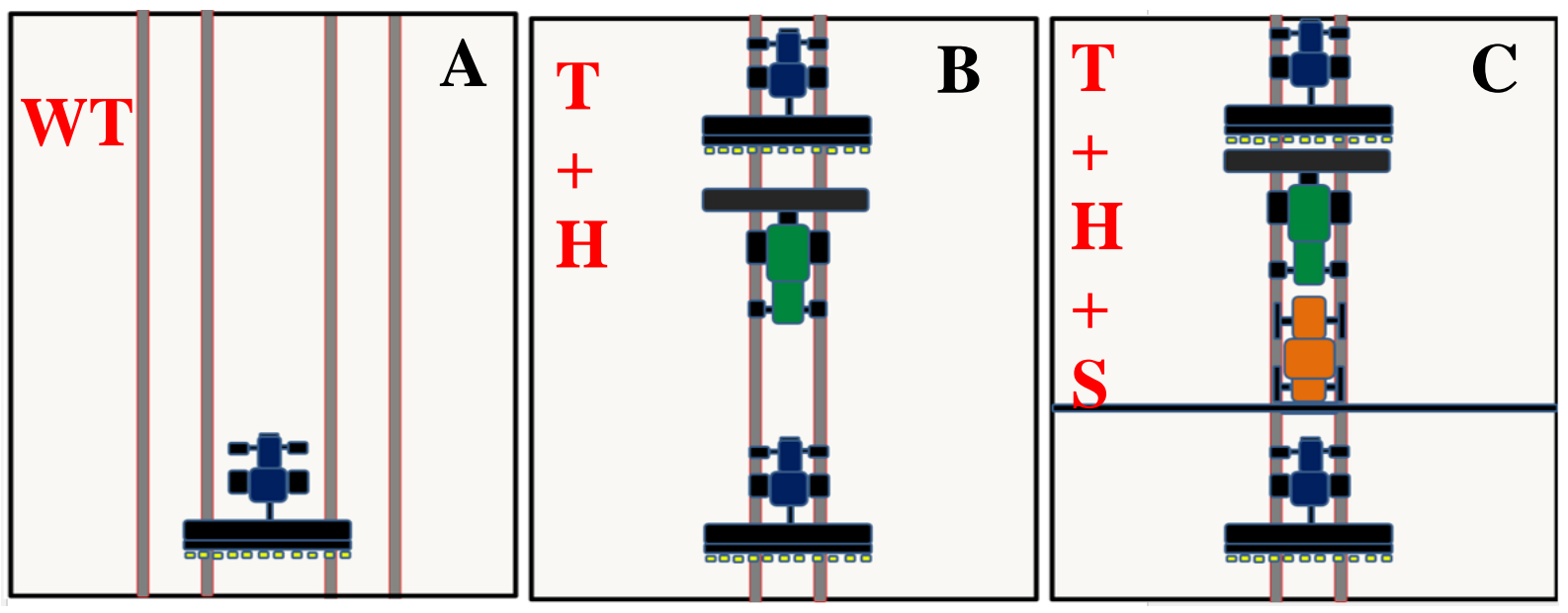

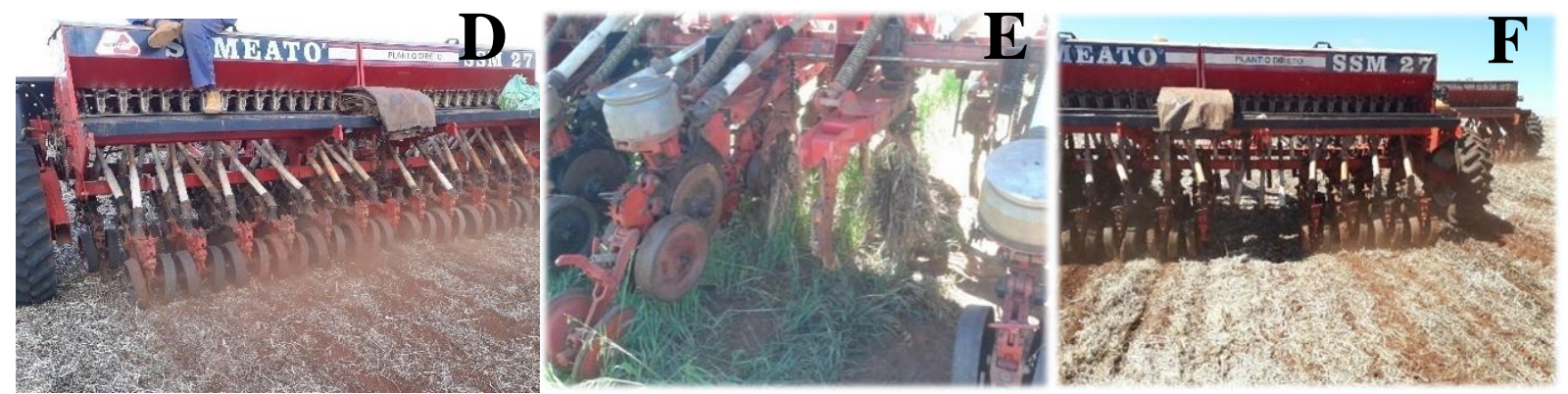

FIGURE 1. Traffic intensities scheme being an area without traffic (WT) (A), tractor + harvester traffic (TH) (B) and tractor + combine harvester + sprayer traffic (THS) (C), double disk configuration (D), double disc with rod (E) and double disc rodless (F).

The configuration of the seeder, which composed the second variation factor, was characterized by the variation of the furrowing system, due to the different intensities of traffic in the previous factor. The initial configuration consisted of 52 furrow double disc type (DD) (Figure 1D) with $0.406 \mathrm{~m}$ and $0.381 \mathrm{~m}$ diameter of the discs, these being fixed in the same turning center. The second configuration was through the association of double disk and furrowing rod (DDwR) (Figure 1E), being 42 double discs of the 52 furrow of the previous situation and the space by those removed occupied by 10 furrow of the rod type, these being located in the rows $14,15,16,17,18,40,41,42,43$ and 44 , counted from left to right of the seeder, which were characterized by coinciding on the traffic lanes of agricultural machine tires. For the third level, the 42 previous double discs were retained and the 10 furrow rods, called double rodless disc (DRID) (Figure 1F).

The spacing of $0.17 \mathrm{~m}$ between the rows and the use of the corrugated cutting discs was maintained, preceding all the rod type furrow with intermediate spring pressure, the same used by the producer during sowing. In the rows configured with a double-disc furrow, the depth control and compression wheels were present and the depth adjustment was maintained at $0.03 \mathrm{~m}$. In the treatment consisting of rows with a furrowing rod, depth control mechanisms were not used and the intermediate pressure in the springs was regulated, and the average depth obtained by their action was then evaluated, which was found in $0.13 \mathrm{~m}$.

All plots were installed homogeneously with the tractor-seeder set, in the second gear of group B and acceleration of the engine in rotation of $1820 \mathrm{rpm}$, regulated by the manual accelerator of the tractor, characterizing speed of $4.2 \mathrm{~km} \mathrm{~h}^{-1}$.

The variables analyzed were traction force, power at the drawbar, maximum power available, actual working speed, skidding, percentage of engine utilization and operational capacity.

Data regarding the tensile force were collected using an electronic instrumentation. The tractive force demanded by the sowing machine in the sowing activity was measured directly by mean of a $100 \mathrm{kN}$ load cell, which generates electric pulses at the same intensity as the required effort, which were stored for later evaluation.

The determination of the power in the tractor drawbar was calculated with the values of the tractive force and real displacement speed of the tractor-seeder set, by [eq. (1)]:

$$
N B=\frac{T f * S r}{3.6}
$$

Where:

$$
\begin{aligned}
& \mathrm{N}_{\mathrm{B}} \text { - Power on the drawbar }(\mathrm{kW}) \\
& \mathrm{Tf} \text { - Tractive Force }(\mathrm{kN}), \\
& \mathrm{Sr}-\text { Real Speed }\left(\mathrm{km} \mathrm{h}^{-1}\right) .
\end{aligned}
$$

The power supplied by the engine is used to balance the required power in a given working condition and is decomposed by [eq. (2)]:

$$
N E=N t+N \delta+N k+N B
$$

Where:

$\mathrm{NE}$ - Power supplied by the engine $(\mathrm{kW})$;

$\mathrm{N}_{\mathrm{t}}$-Power used in the transmission of the engine drive wheels $(\mathrm{kW})$;

$\mathrm{N}_{\delta}$ - Power consumed by skidding $(\mathrm{kW})$;

$\mathrm{N}_{\mathrm{k}}$ - Power used to overcome rolling resistance $(\mathrm{kW})$,

$\mathrm{N}_{\mathrm{B}}$ - Power on the drawbar $(\mathrm{kW})$.

For determining the power supplied by the engine, it was necessary to discount the ways in which this power is lost until it reaches the point of use. From this deduction, it is possible to find the value of the total produced, estimating the losses of the power in the transmission and the skidding by means of eqs (3) and (4).

$$
N t=N E * \eta t
$$

Where:

$\mathrm{Nt}$ - Power used in the transmission of the engine $(\mathrm{kW})$;

$\mathrm{NE}$ - Power supplied by the engine $(\mathrm{kW})$,

$\eta \mathrm{t}$ - Efficiency of transmission (0.85).

$$
N \delta=\frac{F t * S t * \delta}{3.6}
$$

Where:

$$
\begin{aligned}
& \mathrm{N} \delta \text { - Power used by skidding }(\mathrm{kW}) \\
& \mathrm{Ft}-\text { Tractive force }(\mathrm{kN}) \\
& \mathrm{St}-\text { Theoretical displacement speed }\left(\mathrm{km} \mathrm{h}^{-1}\right), \\
& \delta \text { - Skidding. }
\end{aligned}
$$

The skidding of the four-wheel drive was evaluated by the installation of inductive sensors, model LM123004PC. It was assembled on all wheelsets of the tractor, where toothed wheels were fixed to the outside by means of adapted supports to the tractor. 
In order to determine the working speed, the time the tractor took to go through $50 \mathrm{~m}$ of each plot was timed. The rolling resistance values $(\mathrm{kN})$ were obtained with the same load cell used in the experiment, installed in another tractor and at the other end connected to an iron chain that was coupled to the test tractor. The data recording was instantaneously by the load readings that represented the rolling resistance values of the test tractor, and were acquired with the engine on and the transmission in neutral mode.

The operational capacity of the tractor-seeder set was estimated considering an operational efficiency of $75 \%$ considering the seeder working width of nine-meter and the displacement speed according to the real speed obtained in the field. The determination of the operational capacity was based on [eq. (5)]:

$$
O C=\frac{\mathrm{Sr} * \mathrm{~W} * \mathrm{OE}}{10}
$$

Where:

$$
\begin{aligned}
& \text { OC - Operational capacity }\left(\mathrm{ha}^{-1}\right) \text {; } \\
& \mathrm{Sr}-\text { Real speed }\left(\mathrm{km} \mathrm{h}^{-1}\right) \text {; } \\
& \mathrm{W} \text { - Working Width }(\mathrm{m}) \text {, } \\
& \text { OE - Operational efficiency (dimensionless). }
\end{aligned}
$$

To verify the contact surface, the tractor was positioned on the ground and the tire contour was marked with white calcitic limestone in order to delimit the impression of the tire on the ground. Soil compaction at the different traffic intensities was evaluated by means of a penetrometer at depth 0 to $0.4 \mathrm{~m}$. Ten readings were performed in each traffic intensity (WT, TC, THS and WT) in the transversal direction of the traffic lane.

The results were tabulated and submitted to analysis of variance, and the means were compared by the Tukey test at $5 \%$ probability.

\section{RESULTS AND DISCUSSION}

The results show a significant interaction between the traffic intensities and the furrowing systems used in this experiment for the variables traction force, real speed, drawbar traction and operational capacity (Table 1). The main effects of this study were the significant difference for all the variables in the furrower options, and only the tractive force and power in the drawbar traction did not show a significant difference in the traffic intensity factor

\begin{tabular}{|c|c|c|c|c|c|c|c|}
\hline \multirow[b]{2}{*}{ Sources of variation } & \multicolumn{7}{|c|}{ Average squares } \\
\hline & $\begin{array}{c}\mathrm{Ft} \\
(\mathrm{kN})\end{array}$ & $\begin{array}{c}\delta \\
(\%)\end{array}$ & $\begin{array}{c}\mathrm{Sr} \\
\left(\mathrm{km} \mathrm{h}^{-1}\right)\end{array}$ & $\begin{array}{c}\mathrm{NB} \\
(\mathrm{kW})\end{array}$ & $\begin{array}{c}\mathrm{NE} \\
(\mathrm{kW})\end{array}$ & $\begin{array}{l}\text { Use } \\
(\%)\end{array}$ & $\begin{array}{c}\text { OC } \\
\left(\mathrm{ha} \mathrm{h}^{-1}\right)\end{array}$ \\
\hline Traffic $(\mathrm{T})$ & 0.39 & $3.57 *$ & $0.005^{*}$ & 1.47 & $21.27 *$ & $8.53 *$ & $0.002 *$ \\
\hline Furrower (F) & $1124 *$ & $20.26^{*}$ & $0.084 *$ & $1464 *$ & $2088^{*}$ & $836.7 *$ & $0.037 *$ \\
\hline $\mathrm{T} \times \mathrm{F}$ & $4.55^{*}$ & 0.56 & $0.006^{*}$ & $5.38 *$ & 5.63 & 2.25 & $0.002 *$ \\
\hline Error & 0.99 & 0.71 & 0.001 & 1.09 & 1.98 & 0.79 & 0.0005 \\
\hline CV $(\%)$ & 4.14 & 40.03 & 0.85 & 3.6 & 2.96 & 2.96 & 0.84 \\
\hline Overall average & 24.08 & 2.11 & 4.37 & 29.06 & 47.49 & 30.05 & 2.76 \\
\hline
\end{tabular}
(Table 1).

TABLE 1. Summary of the ANOVA with mean squared values for the tractive force $(\mathrm{Ft})$, skidding $(\delta)$, real speed $(\mathrm{Sr})$, traction drawbar (NB), maximum power supplied by the engine (NE), use of the engine and operational capacity (OC), for traffic intensities, furrower options, their interaction, error, coefficient of variation and general average.

* Significant effect $(\mathrm{p} \leq 0.05)$.

When analyzing the general average of the variables studied in this research, it was verified that the values found were low when compared to those referenced by ASAE standard (ASAE, 1999), which, for the operation of seeders of large grains (precision seeders), in the horizontal direction of the displacement, already included the rolling resistance of the machine with good sowing bed, varies from $900 \mathrm{~N}( \pm 25 \%)$ per row (sowing only) and of 3,400 N $( \pm 35 \%)$ of variation per row (sowing and fertilization).

In this sense, considering $900 \mathrm{~N}$ per row of the seeder for using only one seeder set per row and multiplied by the average of 48 rows, according to the average number of rows of the three configurations tested, totalizes a tractive force of $43.2 \mathrm{kN}$ which is higher to $24.08 \mathrm{kN}$ found in this research (Table 1).

The power in the drawbar (NB), considering the average speed of $4.37 \mathrm{~km} \mathrm{~h}^{-1}$, was $52.44 \mathrm{~kW}$ which is approximately double when compared to the average found in this study that was only $29.06 \mathrm{~kW}$ (Table 1). Reduced results were also found by Rodrigues et al. (2011) evaluating the energy demand of a seeder of 17 rows in sorghum sowing, where they found $10.87 \mathrm{~kW}$ of power in the drawbar ( $0.64 \mathrm{~kW}$ per row). Results that are similar to the data of this study, if extrapolated to the average of 48 rows in the seeder, would represent $30.69 \mathrm{~kW}$ of power in the drawbar, which is very close to the $29.06 \mathrm{~kW}$ found.

This low power in the drawbar can be justified by the configuration of the seeder rows, seeding depth and speed of operation used in this study. The configurations of the rows of the sowing machine were composed by a double disk type furrow, with the function of furrow opening and deposition of the seed and fertilizer (phosphorus) in the same furrow, with depth control wheels. In this way, due to the low seeding depth $(0.03 \mathrm{~m})$ and operating in a large traffic-free area $(81.2 \%)$, together with a low operating speed $\left(4.37 \mathrm{~km} \mathrm{~h}^{-1}\right)$, may have required little power demand on the tractor's drawbar.

Analyzing the interaction between intensity of traffics and furrow options, it is observed that the tractive force was higher in the $\mathrm{TH}$ traffic, not different from the THS in the configuration of DDwR (Table 2). 
TABLE 2. Traction force $(\mathrm{kN})$, displacement speed $\left(\mathrm{km} \mathrm{h}^{-1}\right)$, power on the drawbar $(\mathrm{kW})$ and operational capacity $\left(\right.$ ha $\left.\mathrm{h}^{-1}\right)$ in an area without traffic (WT), with tractor and harvester $(\mathrm{TH})$ traffic and with tractor, harvester and sprayer traffic (THS) in the configurations of double disk type, double disk with rod and double disk rodless.

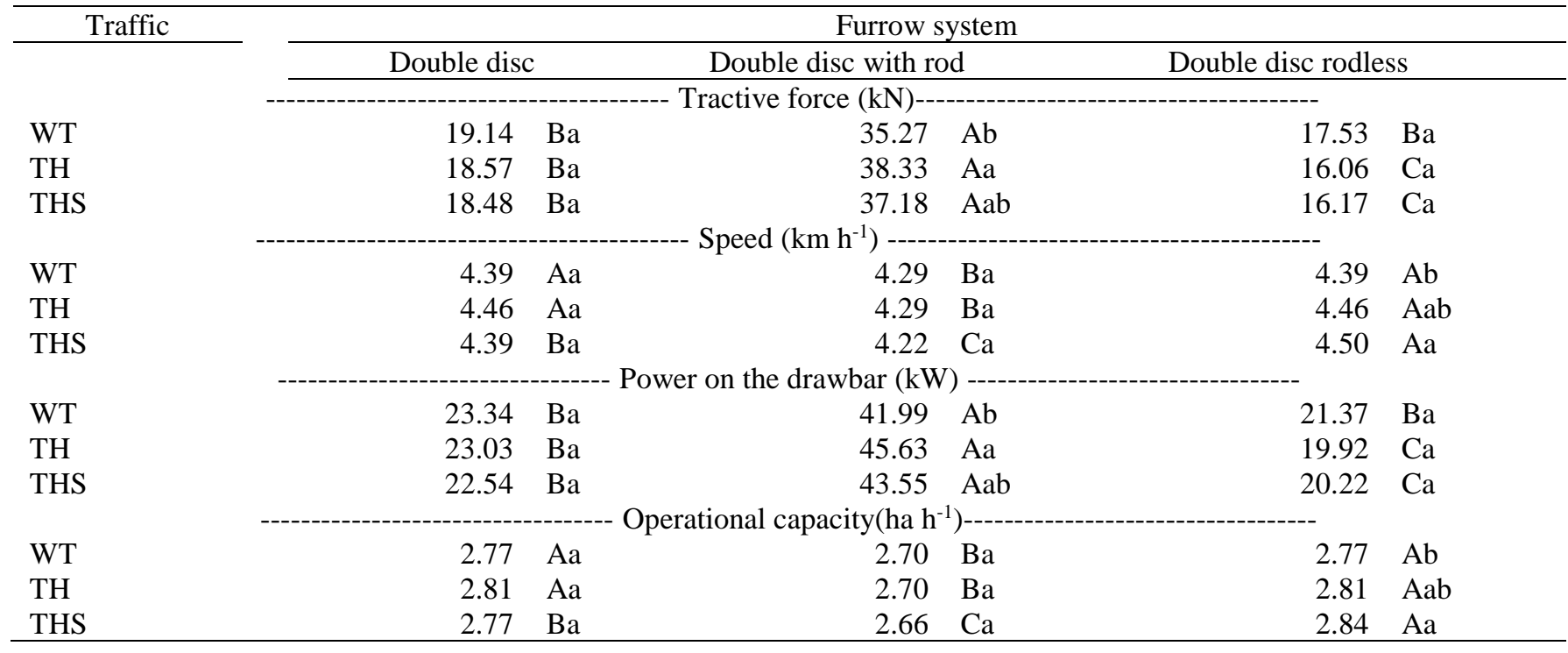

* Means followed by the same lowercase letter in the column and uppercase in the row in each variable, do not differ by Tukey's test ( $\mathrm{p} \leq 0.05)$.

The tractive force results show the objective of this configuration used in the seeder, which consists of the simple opening of the furrow where there is no compaction (double disc) and the opening of the furrow with decompression of the soil (rod), in those places that received the traffic of machinery tires. However, it requires greater tractive force to break through these compacted layers generated by the localized traffic of the machines when using furrower of rod type.
When analyzing the compaction generated by the traffic of the machines through a penetrometer, it is observed, even without statistical analysis, that the higher compaction occurs in the traffic of the $\mathrm{TH}$, followed by the THS traffic in the surface profile of the soil (Figure 2), where it occurs the performance of the furrower mechanisms of the seeder. In this sense, the higher tractive force requirement of the tractor to drive the seeder when using DDwR can be attributed to this compaction generated by the traffic of the machines.

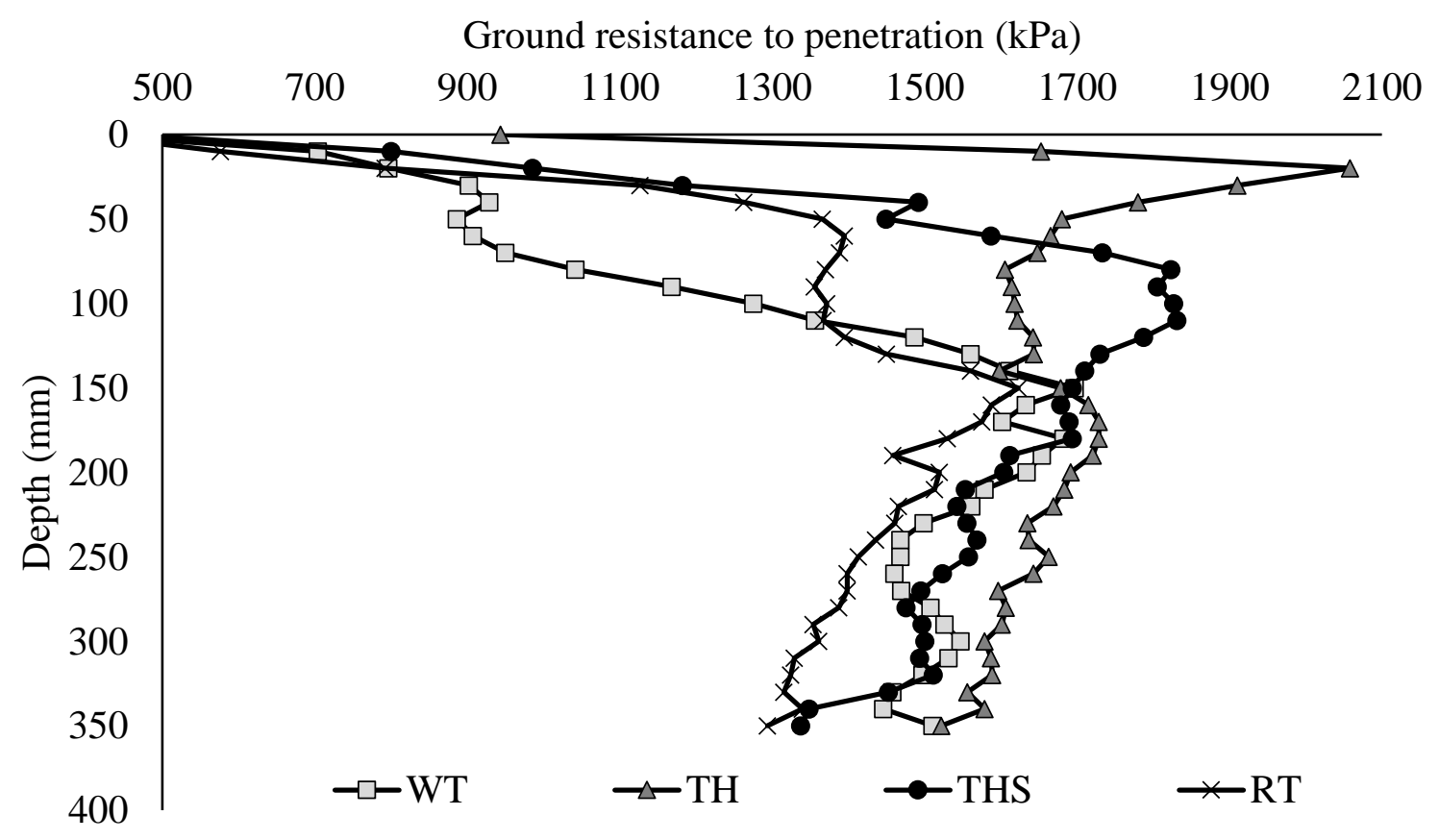

FIGURE 2. Soil penetration resistance $(\mathrm{kPa})$ in soil depth $(\mathrm{mm})$, measured in area without traffic (WT), with tractor and harvester traffic (TH), with tractor, harvester and sprayer traffic (THA) and random machine traffic (RT). 
For the other options of furrow, the traffic intensities did not present a significant difference (Table 2). This result can be attributed to the lower depth of actuation of the double disc furrow mechanism when compared to the rod. In this study, the double discs of the seeder machine operated at a depth of $0.03 \mathrm{~m}$, not having high resistance to penetration at this depth when compared to the performance of the rods, which reached greater depth in the vertical profile of the soil with greater resistance to penetration (Figure 2).

When analyzing the furrowing systems at each traffic intensity, it is observed that the tractive force was higher in the DDwR furrower for all traffic intensities (Table 2). Evaluating different furrowers, Levien et al. (2011) also found a higher requirement for traction for the fixed furrow opening elements when compared to moving elements. By providing greater friction with the ground and depth of actuation, different from the discs that only open the furrows, the rods become more energy demanding to perform their work, requiring for this, greater power of the tractor in the form of traction.

The lowest traction force was observed in the DDwR furrowing system for the traffic intensities evaluated, except in the WT area that did not differ from the DD furrowing system (Table 2). Based on Table 2, and calculating the percentage value of reduction of the tractive force, the absence of furrows in the traffic lanes compared to the use of furrows with rods (DDwR to DRID) provided a reduction of $56 \%$ of tractive force. When the rods were replaced by double disc (DDwR to DD) this decrease was $50 \%$ in the tractive force.

The displacement speed, analyzing the traffic intensities in each furrower option, was higher in the THS traffic, not statistically differing from the $\mathrm{TH}$ traffic in the DDwR furrower configuration (Table 2). This result, when analyzed in percentage based on the values in Table 2 , the traffic controlled in the highest intensity (THS) provided $2.4 \%$ higher speed when compared to WT area.

Furlani et al. (2005) reported higher average speed at no tillage system in relation to soil preparation with scarifier. The result of these authors can explain the data obtained in this study, due to the greater density in the traffic lanes compared to the WT area, favoring the displacement of the tractor and seeder set.

Analyzing only the DDwR option, the lowest displacement speed was evidenced in the WT situation (Table 2). This result can be justified by the greater area of contact of the tire with the soil, which in this study presented the highest value when compared to situations with more intense traffic (Figure 3). This greater contact area causes the tires to have greater adhesion with the ground being able to interfere in the displacement speed of the tractor-seeder set.

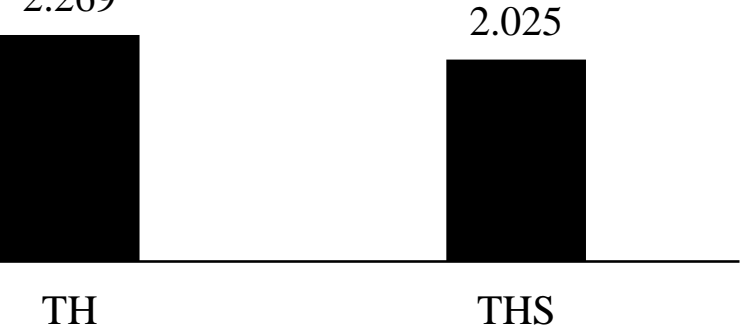

FIGURE 3. Contact area $\left(\mathrm{cm}^{2}\right)$ of the tractor tires in area without traffic (WT), with tractor and harvester traffic (TH) and with tractor, harvester and sprayer traffic (THS).

Allied the contact area of the tire with the ground, the rolling resistance imposed on the tractor tires can also interfere with the displacement speed. In this study, it was verified that the higher rolling resistance was obtained in the WT situation when compared to the other intensities studied (Figure 4). This demonstrates that the greater resistance offered by the ground to the tires, can reduce the displacement speed of the tractor as observed in this study. In the other furrower options, the traffic intensities showed no significant difference in the displacement speed (Table 2).
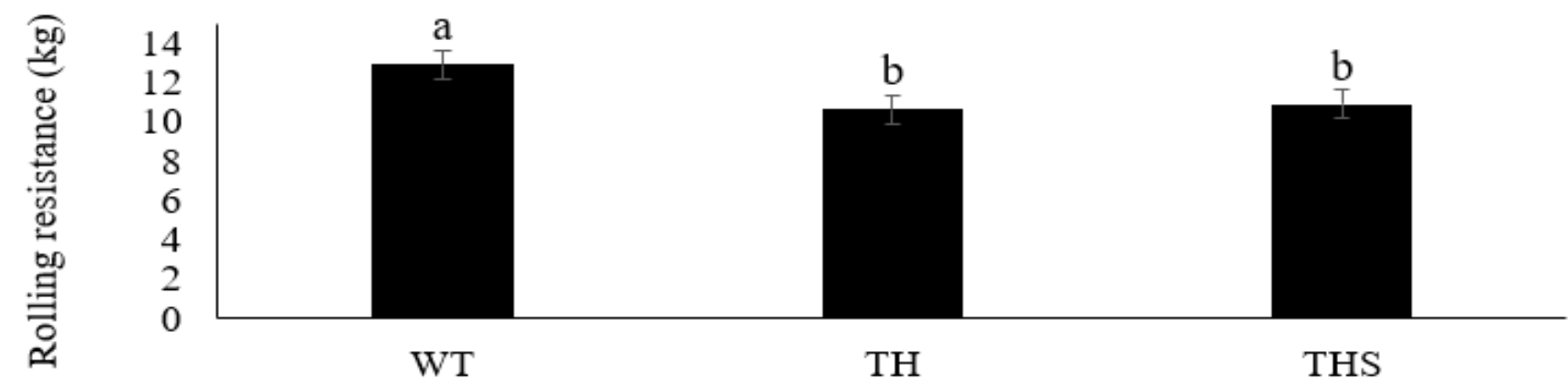

* Means followed by the same letter do not differ by Tukey test $(\mathrm{p} \leq 0.05)$.

FIGURE 4. Rolling resistance $(\mathrm{kN})$ of the agricultural tractor in an area without traffic (WT), with tractor and harvester traffic (TH) and with tractor, harvester and sprayer traffic (THS). 
Analyzing the configurations of furrowers in each traffic intensity, it was verified that the tractor and the seeder speed were higher in the DRID and DD furrower configuration in the traffic-free situation and in the $\mathrm{TH}$ (Table 2). It is observed, when transforming the data of Table 2 in percentage value, that the use of rods in the traffic lanes (DRID for DDwR) in the THS system, reduced the speed in $6.2 \%$.

According to Silveira et al. (2005), the working speed of a seeder is directly related to the force required for the tractor to be able to drive it, being lower as the demand on traction increases. In this study the use of double disk replacing the rods and the absence of furrows in the traffic lanes, demanded lower tractive force (Table 2), which resulted in a higher displacement speed.

The power in the drawbar analyzing the traffic intensities in each furrows option, was higher in TH traffic, not statistically different from THS in the DDwR configuration (Table 2). Silveira et al. (2013) report that several factors are responsible for the force requirement in the drawbar, such as: model of the furrowing rod, seeding depth, fertilization, water content, type of soil and its preparation, size and load of the seeder. In this study, this higher power in the drawbar can be attributed to the soil type and its handling, when it comes to the traffic intensity, because the history of the TH and THS traffic may have left the soil with greater difficulty in the furrow opening, when compared to WT situation.

The lower power in the drawbar was observed in the DRID configuration for the traffic intensities evaluated, except for the WT situation that did not differ from the DD configuration (Table 2). Based on the values in Table 2 and turning them into percentage values, it is observed that the absence of rod-type furrows in the traffic lanes (DDwR to DRID) provided a reduction in the power of the drawbar of $50.8 \%, 57.9 \%$ and $53.5 \%$ in the WT, TH and THS areas, respectively.

This result can also be attributed to the smaller number of furrows used between the three configurations studied, which were 52 for the DD and DDwR treatments, and 42 for the DRID system because the traffic lanes of the tires were not cultivated. However, this high percentage reveals the high power in the drawbar required by the action of these furrows, which was higher than $50 \%$ in all traffic intensities.
The WT situation may not have differed between DD and DRID, because of the reduced tire passages and, consequently, low soil resistance offered to this mechanism, different from the higher intensities of the tested traffics, where the withdrawal of the furrows required less power in the tractor drawbar.

The operational capacity, analyzing the traffic intensities in each furrows option, was higher in the THS traffic, not statistically differing from the $\mathrm{TH}$ traffic in the DRID configuration (Table 2). The consolidation of the soil caused by the traffic of the machines, together with the removal of the furrows operating in this area (DRID), may have favored the increase of the operational capacity when compared to the ground, that does not receive the traffic of machines and it becomes less consolidated reducing the displacement speed as observed in Table 2 and, consequently, the operational capacity. The DD and DDwR configuration did not present statistical differences in traffic intensities (Table 2).

Analyzing the furrows configurations at each traffic intensity, the highest operational capacity was observed in the DD and DRID configuration for all intensities, except THS traffic that was higher only for DRID (Table 2). The lower operational capacity was observed in the DDwR furrower configuration for all traffic intensities (Table 2).

When analyzing the percentage contribution of the controlled traffic of machines between the furrows configurations evaluated, based on the values in Table 2, it is observed that the absence of furrower (DRID) in relation to the DD and DDwR configurations in the highest traffic intensity (THS) increase operational capacity by $2.5 \%$ and $6.3 \%$, respectively.

This study reveals that the operational capacity in the sowing operation can be greater with the technique of controlled traffic of machines, for accumulating the passages of the machines in the same place and to favor the movement of the same ones. The correct adjustment of the configuration of the furrows that, in addition to increasing the performance of the set, can provide reduction of costs by the lower power requirement.

Analyzing the main effects, it is observed that the skidding was higher in the WT area, not statistically different from the THS traffic (Table 3). When analyzing the main effects, it can be observed that the furrowing systems in the DDwR configuration presented the greatest slippage when compared to the other furrows options (Table 3).

TABLE 3. Skidding (\%), engine power $(\mathrm{kW})$ and engine utilization $(\%)$ for areas without traffic (WT), tractor and harvester traffic (TH) and tractor, harvester and spray traffic (THS), in double disk (DD), double disk with rod (DDwR) and double disk rodless (DRID) configurations.

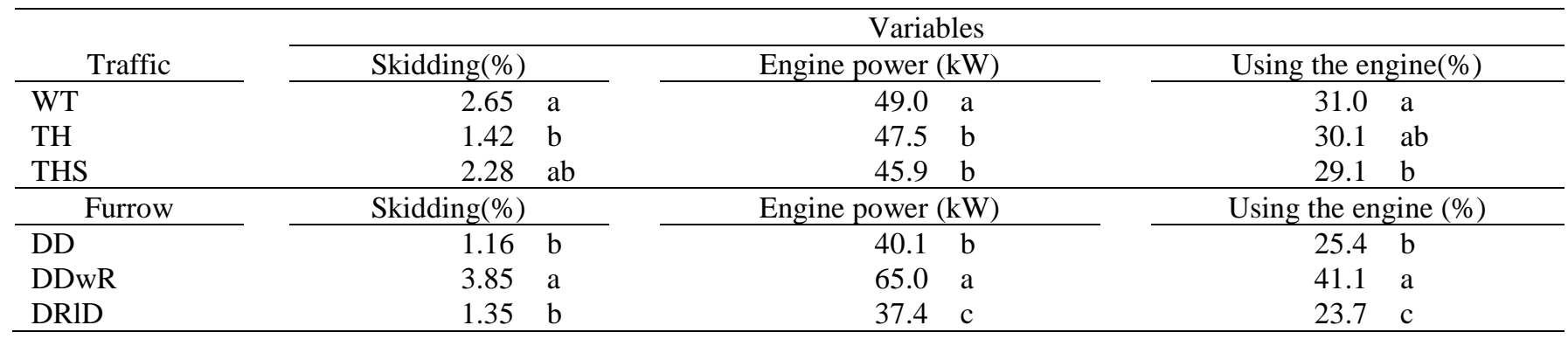

* Means followed by the same letter in the column for each variable do not differ by Tukey test $(\mathrm{p} \leq 0.05)$. 
The power supplied by the engine was higher in the WT area compared to the other machine traffic intensities (Table 3). This result, although, did not show significant interaction to evaluate in which furrow options is more intense, demonstrates that controlled traffic of machines requires less power provided by the tractor engine. This may represent greater gains in efficiency in the use and reduction of the inputs use, such as fuel consumption and pollutant emissions.

Analyzing the furrowing systems, the higher power supplied by the engine was observed in the use of DDwR (Table 3). According to Francetto et al. (2016), the rod type furrower requires greater strength and power than the mismatched double discs, and both when combined with cutting discs have their requirements increased. This increased requirement on power and strength may justify this increase in the maximum available power of the engine found in this study with the use of DDwR.

The highest use of the engine was observed in the WT area, not statistically different from the TH traffic (Table 3). The existence of a soft soil resulting from the absence of machine traffic may have required more demand from the tractor engine to overcome the rolling resistance (Figure 3) and thus use more engine power. By analyzing the furrowing systems, the greater use of the engine occurs in the use of DDwR (Table 3).

These results of tractor performance, in the sowing operation in an area with controlled traffic of machines, express the importance and the benefits in using different configurations in the sowing machine, especially when there is variation of the intensity of compaction of the area and if it occurs in specific locations, such as the use of controlled traffic in machinery, that happens in traffic lanes.

\section{CONCLUSIONS}

The absence of furrows in the controlled traffic lanes provides reduction of the tractive force. When the rods are replaced by double disc, there is also decrease.

The power demand of the seeder decreases when the rod-type furrow is replaced by a double disc and this reduction is even greater when the furrows are removed from the traffic lanes in situations of greater traffic intensity.

\section{REFERENCES}

ASAE - American Society of Agricultural Engineers (1999) Agricultural machinery management. In: ASAE standards 1999: standards engineering practices data. ASAE, p359-66.

Cepik CTC, Trein CR, Levien R, Conte O (2010) Força de tração e mobilização do solo por hastes sulcadoras de semeadoras-adubadoras. Revista Brasileira de Engenharia Agrícola e Ambiental 14(5):561-566. DOI: https://doi.org/10.1590/S1415-43662010000500015

Chen H, Yang Y (2015) Effect of controlled traffic system on machine fuel saving in annual two crops region in North China Plain. Soil \& Tillage Research 153:137-144. DOI: https://doi.org/10.1016/j.still.2015.06.001
Cortez JW, Olszevski N, Pimenta WA, Patrocínio Filho AP, Souza EB, Nagahama DJ (2014) Avaliação da intensidade de tráfego de tratores em alguns atributos físicos de um Argissolo Amarelo. Revista Brasileira de Ciência do Solo 38:1000-1010. DOI: http://dx.doi.org/10.1590/S010006832014000300032

Francetto TR, Alonço AS, Bellé MP, Veit A, Silva WP (2016) Força de tração e potência demandada por mecanismos de corte e sulcadores de semeadora-adubadora. Energia na Agricultura, Botucatu 31(1):17-23. DOI: http://dx.doi.org/10.17224/EnergAgric.2016v31n1p17-23

Furlani CEA, Lopes A, Silva RP (2005) Avaliação de semeadora-adubadora de precisão trabalhando em três sistemas de preparo do solo. Engenharia Agrícola 25(2):458464. DOI: http://dx.doi.org/10.1590/S010069162005000200019

Levien R, Furlani CEA, Gamero CA, Conte O, Cavichioli FA (2011) Semeadura direta de milho com dois tipos de sulcadores de adubo, em nível e no sentido do declive do terreno. Ciência Rural 41(6):1003-1010. DOI: http://dx.doi.org/10.1590/S0103-84782011000600014

Mazurana M, Fink JR, Silveira VH, Levien R, Zulpo L, Brezolin D (2013) Propriedades físicas do solo e crescimento de raízes de milho em um Argissolo Vermelho sob tráfego controlado de máquinas. Revista Brasileira de Ciência do Solo 37(5):1185-1195. DOI: http://dx.doi.org/10.1590/S010006832013000500008

Nunes MR, Denardin JE, Pauletto EA, Faganello A, Pinto LFS (2015) Mitigation of clayey soil compaction managed under no tillage. Soil and Tillage Research 148:119-126. DOI: https://doi.org/10.1016/j.still.2014.12.007

Rodrigues JGL, Gamero CA, Nascimento FM (2011) Demanda energética de máquinas agrícolas na implantação da cultura de sorgo forrageiro. Energia na Agricultura 26:65-72. DOI: http://dx.doi.org/10.17224/EnergAgric.2011v26n1p65-76

Roque AAO, Souza ZM, Barbosa RS, Souza GS (2010) Controle de tráfego agrícola e atributos físicos do solo em área cultivada com cana-de-açúcar. Pesquisa Agropecuária Brasileira 45(7):744-750. Available in:

http://ainfo.cnptia.embrapa.br/digital/bitstream/item/105726/1 /Controle.pdf

Rosset J, Rampim L (2013) Agricultura de precisão: Tráfego controlado. Revista Plantar 68.

Silveira JCM, Fernandes HC, Modolo AJ, Silva SL, Trogello E (2013) Demanda energética de uma semeadora-adubadora em diferentes velocidades de deslocamento e rotações do motor. Revista Ciência Agronômica 44(1):44-52.

Silveira JCM, Modolo AJ, Silva SL, Gabriel Filho A (2005) Força de tração e potência de uma semeadora em duas velocidades de deslocamento e duas profundidades de deposição de semente. Revista Brasileira de Engenharia Agrícola e Ambiental 9(1):125-128. DOI: http://dx.doi.org/10.1590/S1415-43662005000100019

Streck CA, Reinert DJ, Reichert JM, Kaiser DR (2004) Modificações em propriedades físicas com a compactação do solo causada pelo tráfego induzido de um trator em plantio direto. Ciência Rural 34(3):755-760. DOI: http://dx.doi.org/10.1590/S0103-847820040000016 